NASA Technical Memorandum 106968

AIAA-95-2936

\title{
A Heated Tube Facility for Rocket Coolant Channel Research
}

James M. Green

NYMA, Inc.

Brook Park, Ohio

Gary M. Pease and Michael L. Meyer

Lewis Research Center

Cleveland, Ohio

Prepared for the

31st Joint Propulsion Conference and Exhibit cosponsored by AIAA, ASME, SAE, and ASEE

San Diego, California, July 10-12, 1995

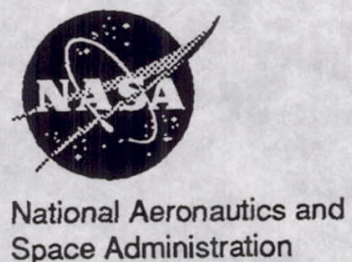

Space Administration 


\title{
A Heated Tube Facility For Rocket Coolant Channel Research
}

\author{
James M. Green \\ NYMA, Inc. \\ Engineering Services Division \\ Brook Park, Ohio \\ Gary M. Pease and Michael L. Meyer \\ NASA Lewis Research Center \\ Cleveland, Ohio
}

\begin{abstract}
The capabilities of a heated tube facility used for testing rocket engine coolant channels at the NASA Lewis Research Center are presented. The facility uses high current, low voltage power supplies to resistively heat a test section to outer wall temperatures as high as $730^{\circ} \mathrm{C}\left(1350^{\circ} \mathrm{F}\right)$. Liquid or gaseous nitrogen, gaseous helium, or combustible liquids can be used as the test section coolant. The test section is enclosed in a vacuum chamber to minimize heat loss to the surrounding system. Test section geometry, size, and material, coolant properties, and heating levels can be varied to generate heat transfer and coolant performance data bases.
\end{abstract}

\section{INTRODUCTION}

Resistively heated tube experiments have a broad history of providing fundamental data from which semi-empirical models of internal flow forced convection have been developed. Many studies of this nature have been conducted to improve the ability to design regeneratively cooled rocket engine thrust chambers using cryogenic coolants such as liquid hydrogen and liquid oxygen. ${ }^{1-3}$ As interest grew in utilizing hydrocarbon rocket fuels, heated tube experiments were conducted on these fuels to investigate their thermal stability, coking properties, and cooling capabilities. ${ }^{4}$

The popularity of heated tube experiments for rocket engine coolant studies is due to two key advantages. First, the entire channel is easily accessible for instrumentation. Extensive temperature and pressure measurements on the heated tubes enables accurate anchoring and development of thermal models. In rocket thrust chamber testing, the difficulty of placing instrumentation accurately and in areas of interest limits the thermal data available from hot-fire tests. The second advantage is that the simplicity of the test hardware permits completely designed experimental matrices to be tested at a reasonable cost. Many tube test sections can be fabricated for the cost of a single hot-fire test engine, and further, the cost of test operation is relatively small.

In light of these benefits, it was determined that two current NASA Lewis Research Center projects were ideally suited for investigation with heated tube experiments. Recent hot-fire tests of hydrogen/oxygen rocket combustors have shown that significant benefits can be achieved using cooling channels with a higher dimensional aspect ratio than are conventionally used. ${ }^{5}$ This hot-fire test information, however, was not complete, and additional parametric studies were required to develop and validate computer models of the complex flow and heat transfer phenomena in the coolant channels.

At the same time, new fuel additives for an existing commercial rocket engine were being considered that could increase the specific impulse of the engine, placing it in a more competitive position with other available launch services. ${ }^{6}$ The cooling performance of the new fuel mixture, however, was not known. Testing was needed to compare the cooling efficiency and channel wall coking of the new fuel mixture with the RP-1 fuel it was intended to replace.

To meet the needs of both programs, a Heated Tube Facility (HTF) was brought on line. The current HTF is a renovated version of a facility which was constructed in the 1960's. This paper will give an overview of the facility and describe the mechanical, electrical, and electronic systems in detail.

Copyright $(\odot)$ by the American Institute of Aeronautics and Astronautics, Inc. No copyright is asserted in the United States under Title 17, U.S. Code. The U.S. Government has a royalty-free license to exercise all rights under the copyright claimed herein for Governmental Purposes. AlI other rights are reserved by the copyright owner. 


\section{FACILITY OVERVIEW}

The Heated Tube Facility is located in the High Temperature Composites Laboratory at the NASA Lewis Research Center, and is capable of testing a variety of fluids, including liquid and gaseous nitrogen, gaseous helium, and combustible liquids. Test fluids which have been used in the combustible liquids rig include RP-1 (kerosene), RP-1 with an azide additive, and JP-7. Figure 1 shows a schematic view of the test complex.

The HTF complex is comprised of four main areas. The test cell area includes the test chamber, nitrogen tank, nitrogen supply system, and the main

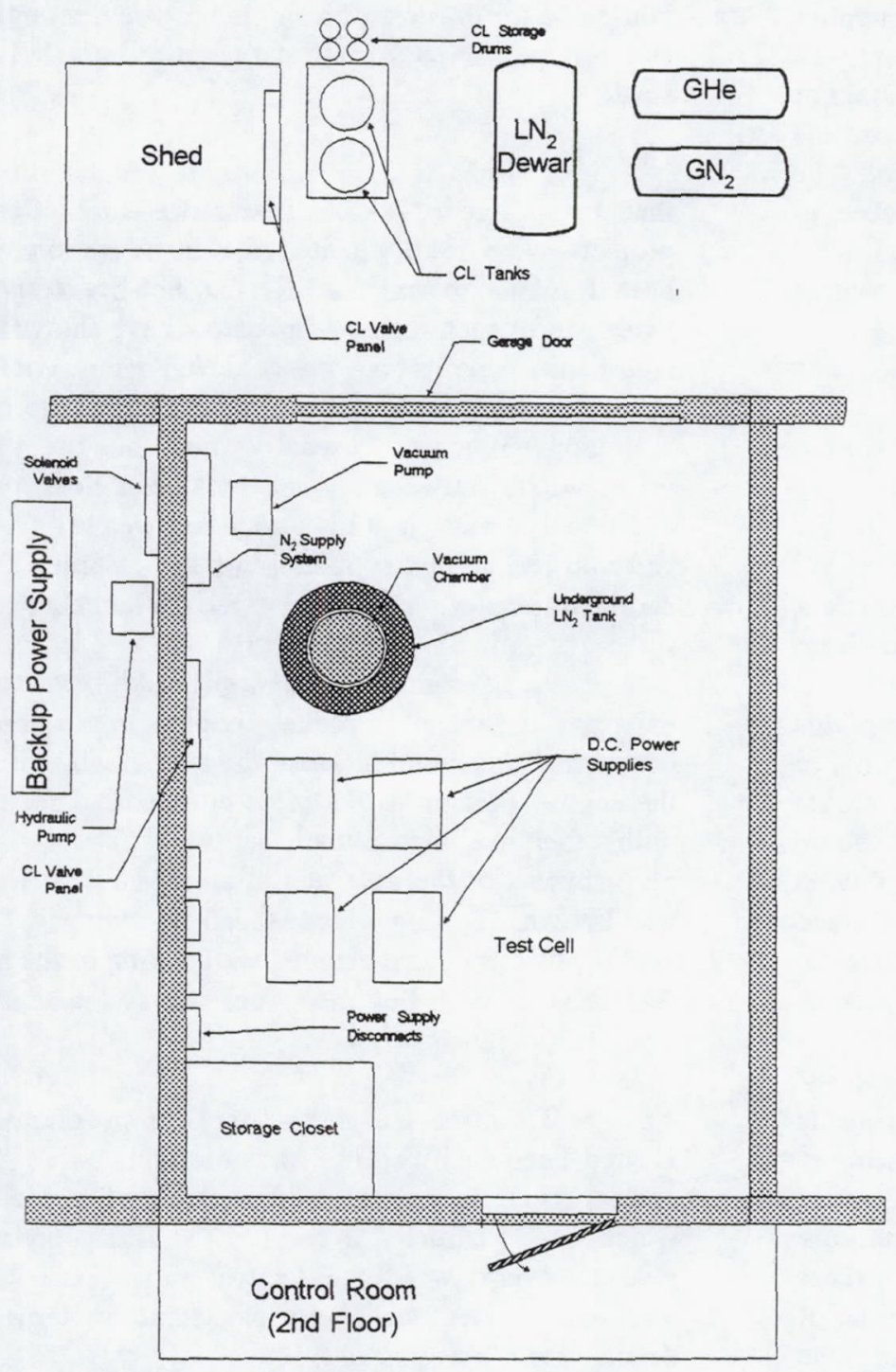

Figure 1: Heated Tube Facility Schematic power supplies. The adjacent room houses the hydraulic pump, the solenoid valves, and the backup power supply. Outside the building is the fluid supply area, which contains the liquid nitrogen $\left(\mathrm{LN}_{2}\right)$ supply dewar, gaseous nitrogen $\left(\mathrm{GN}_{2}\right)$ and helium (GHe) accumulators, and the combustible liquid tanks and flow system components. Finally, the control room is located on the second floor. The main test cell area is $4.6 \mathrm{~m}$ ( $15 \mathrm{ft})$ wide by $12.2 \mathrm{~m}$ ( $40 \mathrm{ft}$ ) long by 6.1 $\mathrm{m}(20 \mathrm{ft})$ high.

In a standard heated tube test, a heavily instrumented metal tube, designed to simulate an actual coolant channel, is mounted in the test chamber and the power supply leads are connected to copper flanges on the test section. After closing the vacuum chamber and establishing a vacuum, the flow is initiated using automatic flow rate and back pressure control. After flow is established, the power supply is turned on and the desired voltage, current, or fluid outlet temperature is set. The data for the test is then recorded, the power supply is turned off, and the flow system is shut down. In analyzing the data, a heat balance is calculated between the power entering the test section and the cooling provided by the flowing fluid, and this heat balance is used to determine the important heat transfer parameters for the test. Destructive testing of the tube is also done to determine wall coking thickness for the combustible liquid tests.

One of the advantages of the HTF is the small support crew required to run a test. Typically, one operations engineer, one mechanic, and one electronics technician operate the facility. This small crew helps to keep test costs low and productivity high. The switchover time to change from using the $\mathrm{LN}_{2}$ system to the combustible liquid system is approximately two weeks.

\section{MECHANICAL SYSTEMS}

The HTF is broken into two distinct test rigs, with the liquid and gaseous nitrogen and gaseous helium supplied by one system (called the $\mathrm{LN}_{2}$ 
system for simplicity), and the combustible liquids supplied by another (called the CL system). The major mechanical capabilities of the various systems are summarized below, and many of the capabilities can be changed or expanded, if future programs demand, with minor system modifications.

\section{Test Chamber}

The focal point of the facility is the vacuum chamber which encloses the research test section. Figure 2 shows a photo of this test chamber. The chamber is a $0.51 \mathrm{~m}$ ( $20 \mathrm{in}$.) diameter by $1.68 \mathrm{~m}$ (66 in.) high cylinder, mounted on top of the $\mathrm{LN}_{2}$ tank which will be described later. The chamber has an inlet on the bottom for the $\mathrm{LN}_{2}$ system and a side inlet for the $\mathrm{CL}$ system, and several vacuum penetrations for instrumentation, the vacuum pump connection, and purging. After passing through the test section, the fluid leaves the chamber through an opening at the top of the chamber. Two different outlet configurations are used depending on the test fluid to avoid contaminating the $\mathrm{LN}_{2}$ system with combustible liquid.

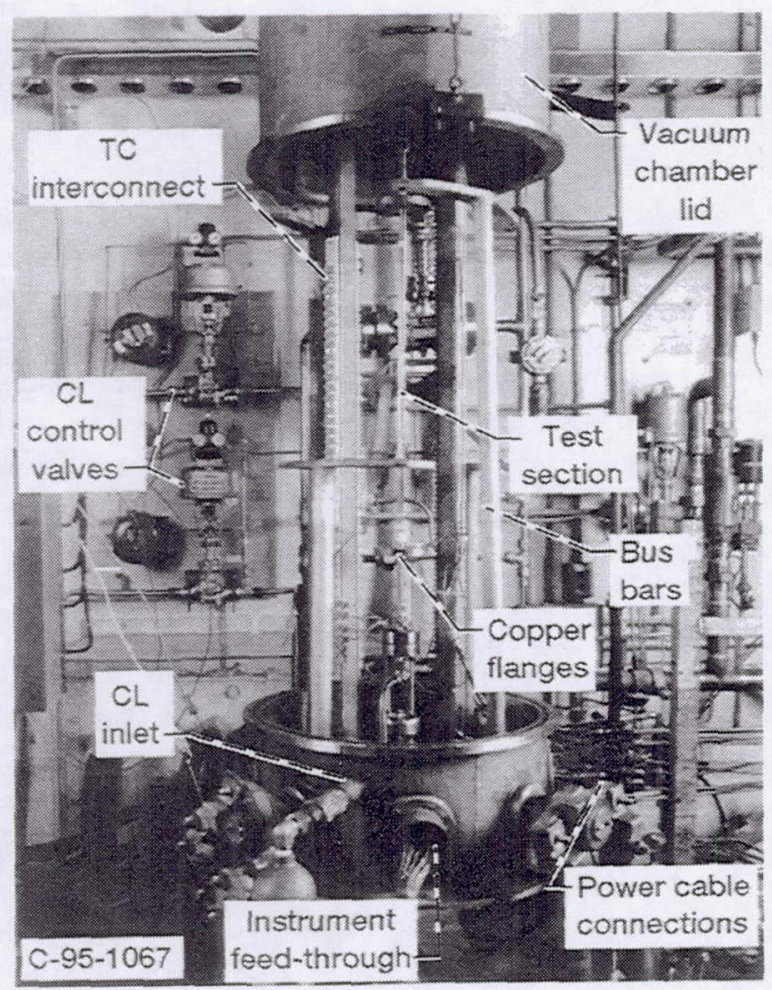

Figure 2: HTF Test Chamber
The connections for the power supply leads are located at four points around the vacuum chamber, with bus bars mounted inside the chamber. The test section is mounted in the center of the chamber and the final power cables are connected from the bus bars to copper flanges on the test article. The test section is electrically isolated from the flow system using flanges with teflon gaskets and bolt sleeves. An interconnect for thermocouples is located inside the chamber to route the thermocouple wires from the test article out of the chamber and to the control room.

Using a $1 \mathrm{HP}$ mechanical vacuum pump, the test chamber is typically pumped down to approximately 350 millitorr during a test run, which is sufficient to minimize the heat loss from the test section to the surroundings due to convection. A vacuum gage in the chamber is used to abort a test if there is a loss of vacuum in the chamber, which might indicate a burst test section. The vacuum pump is protected by a remote shutoff valve, which closes upon loss of vacuum in the chamber, and a burst disk to prevent sudden overpressurization of the chamber.

\section{Liquid Nitrogen System}

As mentioned above, this section will encompass the use of $\mathrm{LN}_{2}, \mathrm{GN}_{2}$, or GHe. These fluids are used in the same supply tank, with only a minor change required in the control parameters to calculate the mass flow of the fluid whether it is a liquid or a gas. The important features of the $\mathrm{LN}_{2}$ system are shown in a simplified flow schematic in Figure 3.

The central feature of the system is the high pressure vacuum jacketed cryogenic tank, which is located in the ground under the vacuum chamber. This tank is filled with $\mathrm{LN}_{2}$ from the $7570 \mathrm{~L}$ (2000 gallon) dewar, with $\mathrm{GN}_{2}$ from the $16.5 \mathrm{MPa}$ (2400 psig) $\mathrm{GN}_{2}$ accumulator, or with $\mathrm{GHe}$ from the 16.5 $\mathrm{MPa}$ (2400 psig) $\mathrm{GHe}$ accumulator, all located outside the building. The tank is rated for $11.4 \mathrm{MPa}$ (1650 psig) maximum pressure, and is protected from overpressurization by a relief valve and burst disc. The tank js $0.50 \mathrm{~m}$ (19.5 in.) in diameter and $2.13 \mathrm{~m}$ (7 ft.) long, with a volume of approximately $0.40 \mathrm{~m}^{3}$ $\left(14 \mathrm{ft}^{3}{ }^{3}\right)$. On a typical run day, four to five tank refills with $\mathrm{LN}_{2}$ can be done, which determines the amount of testing that can be done per test day. Refill time using $\mathrm{GN}_{2}$ or $\mathrm{GHe}$ is negligible. 


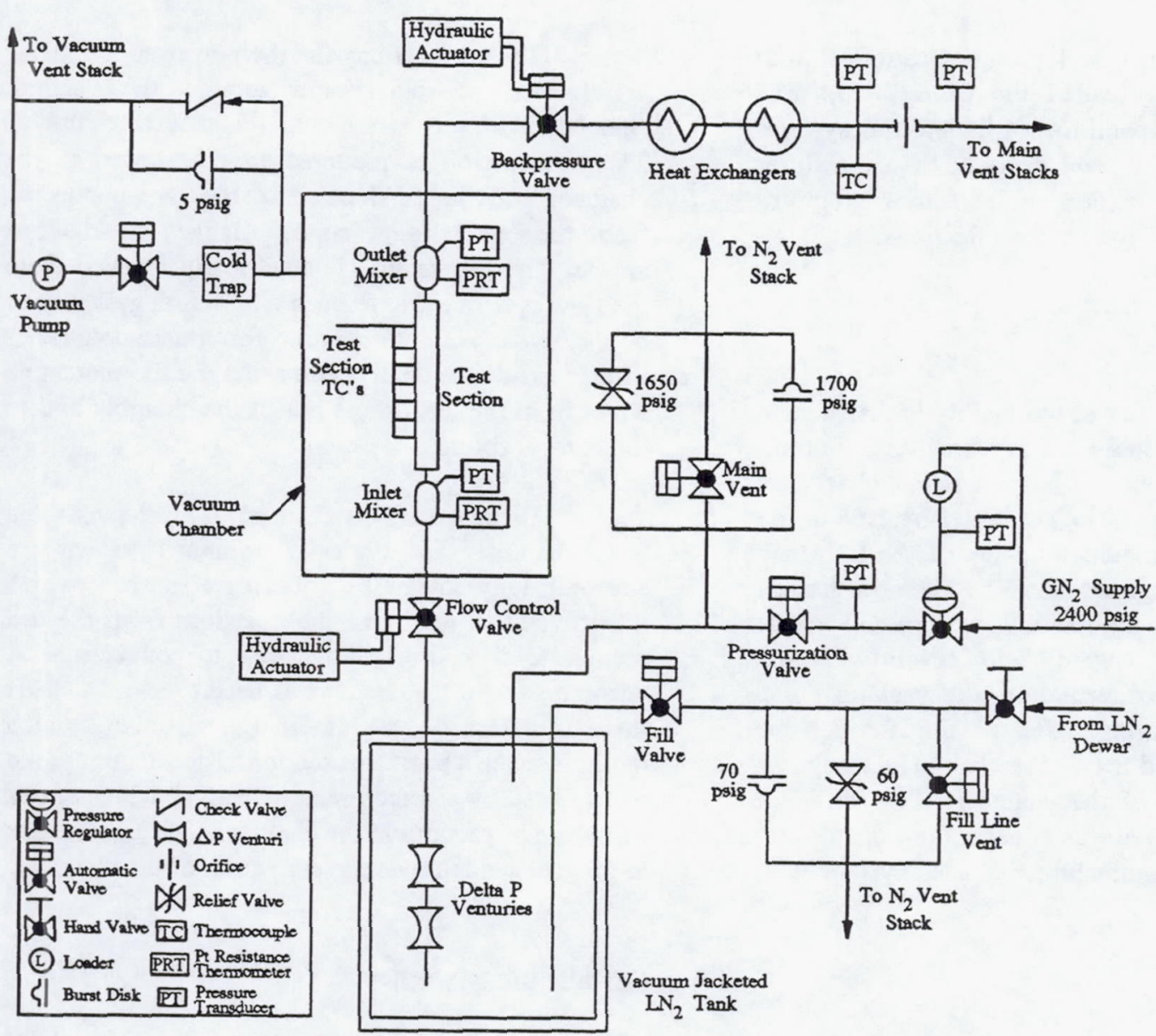

Figure 3: $\mathbf{L N}_{\mathbf{2}}$ Flow System Schematic $\mathrm{lbm} / \mathrm{s}$ ) can be used, with similar pressure conditions. $\mathrm{GHe}$ testing has not been conducted to date, but flow rates in the range of 0.02 to $0.05 \quad(0.04$ to $0.10 \mathrm{lbm} / \mathrm{s}$ ) can be expected with similar pressure conditions. All of the flow rate ranges can be modified with minor changes to the control valves. With the given tank size, the maximum test duration using $\mathrm{LN}_{2}$ is 7 to 15 minutes, depending on the flow rate. Gaseous test durations are extremely long and are only

To flow the fluid through the test section, the tank is pressurized with nitrogen (or helium) gas. A remote operating loader is used to set the dome pressure in the main pressure regulator which determines the tank pressure. After the tank is set to the correct pressure, the required flow rate and back pressure are set and the test is initiated using automatic control. The mass flow rate is calculated using a $\Delta \mathrm{P}$ venturi. Before and after passing through the test section, the fluid passes through mixer sections which allow the fluid to come to thermal equilibrium. The inlet and outlet temperatures and pressures for the test are measured in these mixers.

Both the flow control and back pressure valves are split body globe valves which are hydraulically actuated using servo controllers. In the current configuration, $\mathrm{GN}_{2}$ flow rates from 0.05 to $0.11 \mathrm{~kg} / \mathrm{s}(0.10$ to $0.25 \mathrm{lbm} / \mathrm{s})$ can be controlled automatically, with typical tank pressures from 3.45 to $10.35 \mathrm{MPa}$ (500 to $1500 \mathrm{psig}$ ) and back pressures from 2.07 to $8.28 \mathrm{MPa}$ (300 to $1200 \mathrm{psig}$ ). $\mathrm{LN}_{2}$ flow rates in the range of 0.27 to $0.59 \mathrm{~kg} / \mathrm{s}(0.60$ to 1.30 limited by the large gaseous supply tanks.

After exiting the back pressure valve, the fluid passes through two steam heat exchangers and is then vented to the atmosphere. The heat exchangers are used for $\mathrm{LN}_{2}$ testing to warm the fluid to a gaseous state before venting. An orifice plate is included downstream of the heat exchangers to verify the accuracy of the flow rate calculated from the $\Delta P$ venturi.

\section{Combustible Liquid System}

Since the combustible fluids cannot be vented to the atmosphere and can be reused for multiple tests, the CL system was designed as a two tank system for supply and return. A schematic of the system is shown in Figure 4. The two tanks used in the system are identical $0.25 \mathrm{~m}^{3}\left(8.7 \mathrm{ft}^{3}\right)$ carbon steel spheres, currently rated for 1650 psig maximum working pressure. If necessary, the tanks are capable of higher rated working pressures with proper 


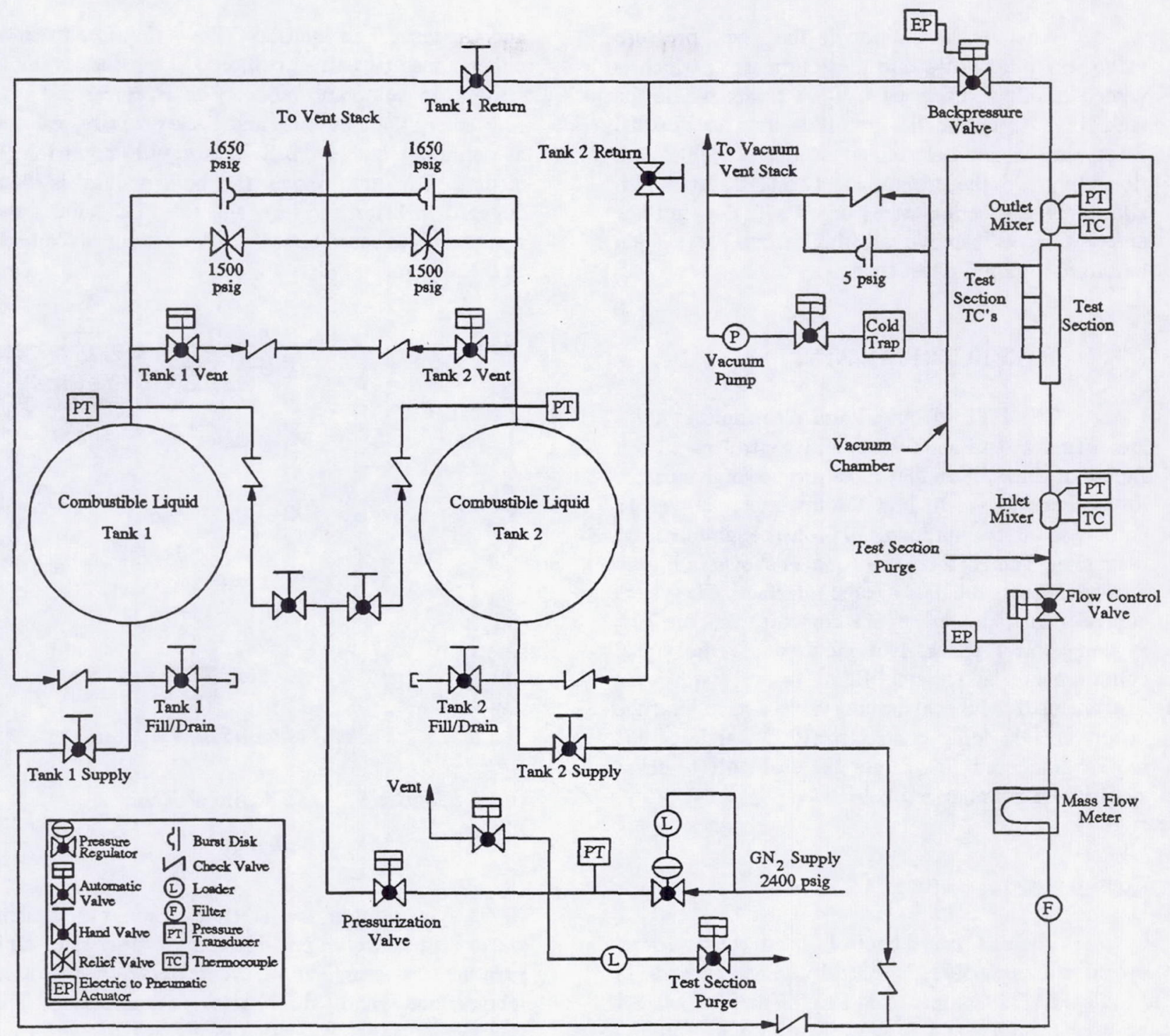

Figure 4: Combustible Liquid Flow System Schematic

recertification. The two tank system allows for the supply and return tanks to be switched after each is emptied, bypassing the need to flow all the fluid back into a single supply tank. To transfer fluid between the $208 \mathrm{~L}$ (55 gallon) supply drums and the tanks, an air actuated pump is used.

In typical operation, the $\mathrm{GN}_{2}$ and $\mathrm{CL}$ supply hand valves to the full tank and the return valve to the empty tank are opened. The full tank is then pressurized to a pre-determined pressure using a dome loaded regulator. Once tank pressure is established, the operator interface program is used to set the required flow rate and back pressure and begin the test.
The control valves for the $\mathrm{CL}$ system are split body globe valves with linear trims, actuated pneumatically using a 4-20 mA signal through an electric to pneumatic valve. The CL system uses a Coriolis force type flow meter to provide accurate measurement of fluids of varying densities. In the current configuration, flow rates from 0.45 to 0.91 $\mathrm{kg} / \mathrm{s}$ ( 1.0 to $2.0 \mathrm{lbm} / \mathrm{s}$ ) can be controlled, with typical tank pressures of 7.59 to $9.66 \mathrm{MPa}$ (1100 to 1400 psig) and typical back pressures of 6.21 to $7.59 \mathrm{MPa}$ (900 to $1100 \mathrm{psig}$ ). The maximum test duration for the CL system is dependent on the flow rate and particular fluid, ranging from 150 to $300 \mathrm{sec}$ for the conditions tested to date. Inlet and outlet mixers are again used to obtain accurate bulk fluid inlet and outlet temperatures and pressures. 
After passing through the back pressure valve, the fluid flows into the return tank, which is vented to allow displaced $\mathrm{GN}_{2}$ to escape while the tank fills. An automatic shutoff is used to stop the flow after a pre-determined weight of fluid has flowed through the system. The two tank system also allows the test section to be purged with $\mathrm{GN}_{2}$ into the empty tank to remove all fluid from the system before changing the test section.

\section{ELECTRICAL SYSTEMS}

The HTF electrical and electronic systems are used for data acquisition and control of all test functions. In addition they must provide high current, low voltage power to heat the test piece as well as automatic safety shutdowns to protect equipment and personnel. The HTF control room is shown in Figure 5 , which shows the data system interface, CL system control panel, power supply controls, and the $\mathrm{LN}_{2}$ system control panel. Not pictured are the signal conditioners and amplifiers used with the instrumentation, the hydraulic valve controllers, the programmable logic controller (PLC), and the PC workstation used to operate the test. All of these systems are summarized below.

\section{Control System}

The PLC based control system consists of an operator's interface, control panels, and a Modicon/AEG Compact 984 PLC. The PLC has 8K of user memory and is capable of up to $256 \mathrm{I} / \mathrm{O}$ points. Other valuable features are its ability to perform proportional integral derivative (PID) loop control and floating point math. In its present configuration, it has the following $\mathrm{I} / \mathrm{O}$ :

- 48115 VAC Inputs

- 48115 VAC Outputs

- 8 Analog Inputs (I or V)

- 4 Analog Outputs (I or V)

- 8 Thermocouple Inputs

The operator interface is shown in Figure 6. The purpose of the interface is to allow the user to operate all modulating control valves in the system. These valves are the back pressure control, flow control, and the main vent valve, which is used to control the tank pressure for the $\mathrm{LN}_{2}$ system. Separate but similar programs are used for the $\mathrm{LN}_{2}$ and $C L$ tests. The interface allows the user to enter either a manual valve position or a process variable setpoint in automatic mode. For a typical test, the user enters the flow rate and back pressure, as well as defining whether the fluid is liquid or gas for $\mathrm{N}_{2}$ testing. The auto mode for both valves is then engaged to begin the test, and the PLC adjusts the control valves based on the process variables fed back to the system.

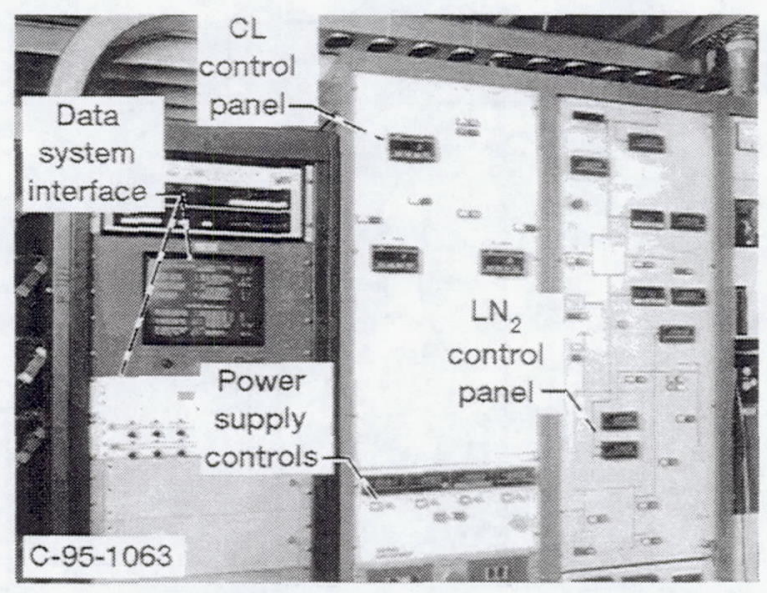

Figure 5: HTF Control Room

In addition, the interface displays the system alarm status, valve positions, mass flow rate, tank pressure and temperature, venturi $\Delta \mathrm{P}$, test section temperature, and fluid inlet temperature. The interface software is written in visual basic and runs on an 80386 based workstation. It communicates with the PLC via Modbus protocol using an RS232 port.

To control the hydraulically actuated flow and back pressure valves, a hybrid circuit consisting of a Moog servo controller and a PID loop in the PLC is used. This allows the valves to be controlled at a speed faster than the PLC is capable of on its own. The PLC uses the operator setpoint and the process variable to generate a valve position command that is sent to the servo controller, which uses the PLC position command and the valve position feedback to control the ultimate position of the valve.

The PLC controls the pneumatic valves by sending a 4-20 mA signal to an electric to pneumatic converter valve, which then sends a proportional pressure signal to the valve actuator. 


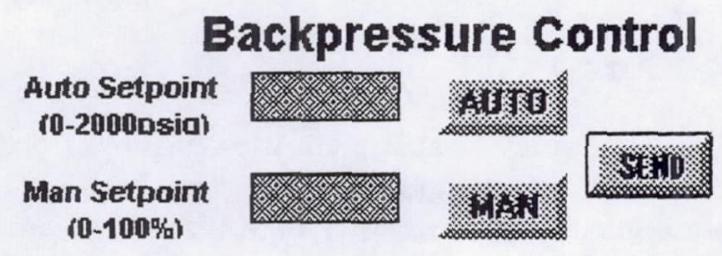

Flow Control
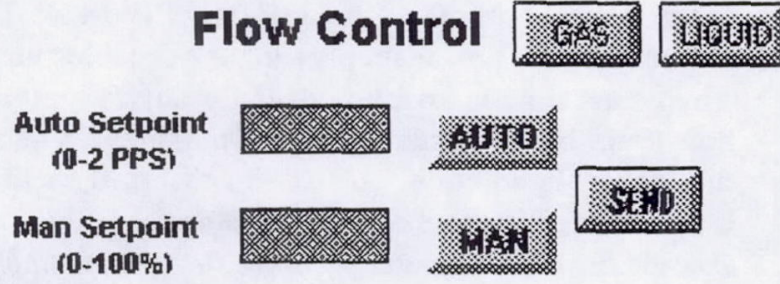

Tank Pressure Control

Auto Setpoint (0-2000Dsia)

Man Setpoint (0-100\%)
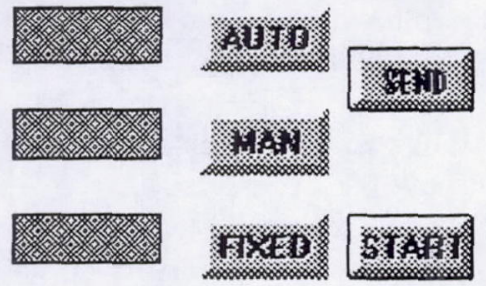

DURATION (1-999 SEC)
\% OPEN

(0-100\%)

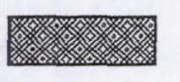

\begin{tabular}{|c|c|c|}
\hline $\begin{array}{c}\text { BackPressure } \\
\text { Dsi }\end{array}$ & \multicolumn{2}{|c|}{ Exit Temp } \\
\hline $\begin{array}{c}\text { Value } \\
\text { Position('\%Onen) }\end{array}$ & Deg R & Deg F \\
\hline
\end{tabular}

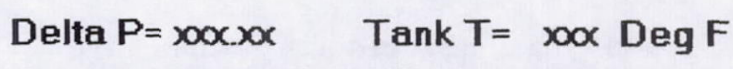

\begin{tabular}{|c|c|c|}
\hline $\begin{array}{c}\text { Mass Flow } \\
\text { (PPS) }\end{array}$ & \multicolumn{2}{|c|}{ Test Section Temp } \\
$\begin{array}{c}\text { Value } \\
\text { Position(\%ODen) }\end{array}$ & Deg & Deg F \\
\hline
\end{tabular}

Alam Status

\begin{tabular}{|c|}
\hline $\begin{array}{c}\text { Tank } \\
\text { Pressure }\end{array}$ \\
\hline $\begin{array}{c}\text { Value } \\
\text { Position(\%ODen) }\end{array}$ \\
\hline
\end{tabular}
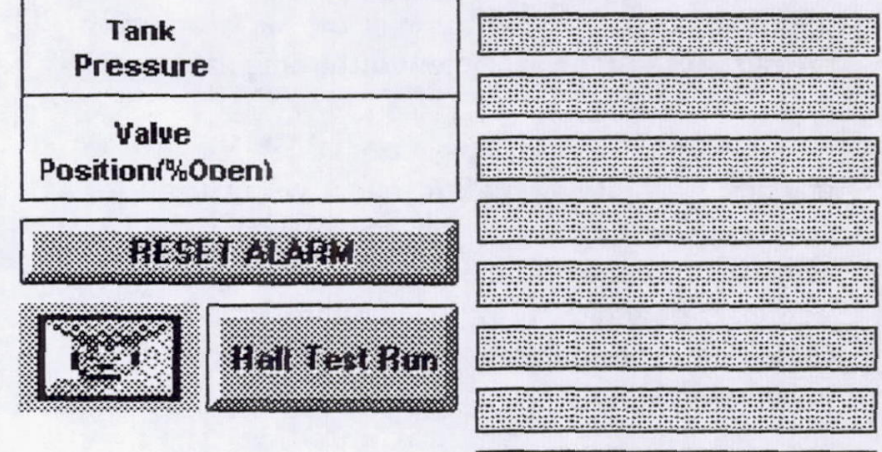

\section{Eivir}

Figure 6: Operator Interface Screen

\section{Power Supply}

The power supply consists of four D.C. arc welding power supplies connected in parallel. Each power supply provides 125 to 1500 Amperes continuous current at 0 to $80 \mathrm{VDC}$, for a total of up to 6000 Amperes current into the test piece. The cables from the power supplies to the vacuum chamber are $750 \mathrm{MCM}$ welding cables connected to four copper feedthroughs in the test chamber. Bus bars inside the chamber (see Figure 2) then route the power to the upper and lower test section flanges through custom made copper jumper cables.

The power supply control circuit uses a 0 to $15 \mathrm{~V}_{\mathrm{dc}}$ signal that ranges the output from minimum to maximum current. The individual power supply controls are coupled using a custom designed 1000 ohm potentiometer on the power supply control panel, allowing the operator to control the overall power supply output. A power supply interlock is used to inhibit power output under specified alarm conditions.
Instrumentation

The primary measurements used in the HTF are temperature, pressure, flow rate, test section current, and test section voltage. Type $\mathrm{T}$ (copperconstantan) and Type K (Chromel-Alumel) thermocouples (TC's) are used to profile temperatures along the test section as well as measure critical facility parameters. A total of $48 \mathrm{TC}$ channels are available in the facility. The TC's run to a $65^{\circ} \mathrm{C}$ $\left(150^{\circ} \mathrm{F}\right)$ reference oven and then onto the data system. A temperature shutdown TC is run directly to a temperature compensated input to the PLC. All TC's are individually fused to protect equipment and personnel from injury due to the high currents in the test section. Test section surface TC's are typically fabricated from 26 gage, fiberglass insulated wire, using Type T or K TC's spotwelded directly to the surface of the test section. Because this method creates a direct electrical contact between the test section and TC, extreme care is exercised in order to align the junction perpendicular to the test section current flow. Otherwise, test section voltage could be 
picked up by the TC. Platinum resistance thermometers (PRT's) are used to measure $\mathrm{LN}_{2}$ tank temperature. Each PRT has its own calibrated signal conditioner. The tank temperature is fed directly into a PLC analog input and is used to calculate $\mathrm{N}_{2}$ density for the flow rate measurement.

Pressures are measured using strain gage type pressure transducers (PT's) ranging from 0 to $20.69 \mathrm{MPa}(0-3000 \mathrm{psig})$. Each PT has its own calibrated strain gage signal conditioner. A total of 35 PT's are available, including those used for facility parameters. Test section coolant pressure taps are attached by counterboring the test section wall for

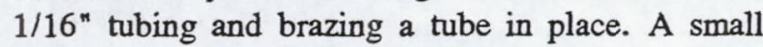
diameter hole is drilled through the wall, allowing pressure measurement without disturbing the flow.

The $\mathrm{LN}_{2}$ system uses a $\Delta \mathrm{P}$ Venturi to measure flow rate. Mass flow rate is calculated using standard flow equations with separate equations to calculate the density of the liquid or gaseous nitrogen. The mass flow rate is calculated by the PLC for flow control and alarm conditions, and is calculated independently by the data acquisition system for data analysis. The CL system uses a Coriolis type flow meter to directly measure mass flow. The meter outputs a frequency that is proportional to mass flow rate, which allows direct measurement of the mass flow rate even with liquids of different densities.

Current is measured using a 6000 Ampere shunt connected in series with the test piece. Voltage is measured across the test piece at the positive and negative bus bar locations.

\section{Data Acquisition System}

The HTF uses a data acquisition system called ESCORT, which is designed for recording steady-state or long duration test runs. The research data typically consist of coolant temperatures, pressures, and flow rates, test section temperatures, and electrical power inputs. The data are digitized locally and recorded at the NASA LeRC Research Analysis Center. The ESCORT system allows up to 131 channels of data to be recorded at a nominal rate of $1 \mathrm{~Hz}$. The raw data are stored for post-processing by both a fortran code and spreadsheet analyses.

\section{Abort System}

A series of aborts are used to protect both personnel and equipment. The test section is susceptible to a catastrophic failure if for any reason current is applied to it without any flow. This is applicable to both the $\mathrm{LN}_{2}$ and the CL tests. To prevent this, the power supply cannot be enabled until a minimum flow is established. If for any reason the flow drops below this level, the power supply will be shut down. In addition, one TC on each test section is sent to the PLC to monitor temperature. If this TC exceeds the high temperature limit, the power supply is shut down and flow through the test section is continued until an acceptable temperature is reached. The following is a list of the aborts integrated into the control system:

- High and Low Inlet Pressure

- Low Back Pressure

- Low Vacuum

- Low Hydraulic Pressure $\left(\mathrm{LN}_{2}\right)$

- Low Mass Flow

- High Flex Hose Pressure $\left(\mathrm{LN}_{2}\right)$

Low oxygen detectors and smoke alarms that work independently of the facility control system are also installed in the facility.

\section{CONCLUSION}

The mechanical, electrical, and electronic capabilities of the NASA Lewis Research Center's Heated Tube Facility have been described, along with an overview of the facility and its potential uses. The HTF provides the flexibility to test a wide variety of sample configurations, coolants, flow rates, and pressures at high temperatures for significant test durations. The $\mathrm{LN}_{2}$ system in the facility has been utilized to study fundamental rocket coolant heat transfer using varying tube geometries and coolant properties, and the combustible liquid system has been used to study coking and heat transfer for a commercial engine, using various combustible liquids, tube diameters, and tube materials.

In addition to the versatile nature of the facility to carry out basic and applied research, the low cost associated with running a test program in the HTF make it an attractive test location, for both inhouse research as well as cooperative agreements with industry. 


\section{ACKNOWLEDGEMENTS}

The authors would like to thank William M. Furfaro, Jr., Clifford R. Naugle, and the rest of the HTF crew for their excellent support in building up and running the facility, and Diane L. Linne for her programmatic support and assistance in operating the combustible liquid system.

\section{REFERENCES}

1. Hendricks, R. C., Graham, R. W., Hsu, Y. Y., And Friedman, R., "Experimental Heat-Transfer Results for Cryogenic Hydrogen Flowing in Tubes at Subcritical and Supercritical Pressures to 800 Pounds Per Square Inch, " NASA TN D - 3095, 1965.

2. Rousar, D. and Miller, F., "Cooling with Supercritical Oxygen," AIAA-75-1248, AIAA/SAE 11th Joint Propulsion Conference, 1975.

3. Niino, M., Kumakawa, A., Yatsuyanagi, N., and Suzuki, A., "Heat Transfer Characteristics of Liquid Hydrogen as a Coolant for the LO2/LH2 Rocket Thrust Chamber with Channel Wall Construction," AIAA-82-1107, 1982.

4. Giovanetti, A. J., Spadaccini, L. J., Szetela, E. J., "Deposit Formation and Heat Transfer in Hydrocarbon Rocket Fuels," AIAA-84-0512, AIAA/SAE/ASME/ASEE 22nd Joint Propulsion Conference, 1984.

5. Carlile, J. A. and Quentmeyer, R. J., "An Experimental Investigation of High-Aspect-Ratio Cooling Passages, " AIAA-92-3154, AIAA/SAE/ASME/ASEE 28th Joint Propulsion Conference, 1992.

6. Volkmann, J. C., "Development of Diazidoalkane Fuel Additives for LOX/RP-1 Booster Engines," AIAA-92-3130, AIAA/SAE/ASME/ASEE 28th Joint Propulsion Conference and Exhibit, 1992. 


\begin{tabular}{|c|c|c|c|}
\hline \multicolumn{3}{|c|}{ REPORT DOCUMENTATION PAGE } & $\begin{array}{l}\text { Form Approved } \\
\text { OMB No. } 0704-0188\end{array}$ \\
\hline \multicolumn{4}{|c|}{$\begin{array}{l}\text { Public reporting burden for this collection of information is estimated to average } 1 \text { hour per response, including the time for reviewing instructions, searching existing data sources, } \\
\text { gathering and maintaining the data needed, and completing and reviewing the collection of information. Send comments regarding this burden estimate or any other aspect of this } \\
\text { collection of information, including suggestions for reducing this burden, to Washington Headquarters Services, Directorate for Information Operations and Reports, } 1215 \text { Jefferson } \\
\text { Davis Highway, Suite 1204, Arlington, VA } 22202-4302 \text {, and to the Office of Management and Budget, Paperwork Reduction Project (0704-0188). Washington, DC 20503. }\end{array}$} \\
\hline 1. AGENCY USE ONLY (Leave blank) & \begin{tabular}{|r|} 
2. REPORT DATE \\
June 1995 \\
\end{tabular} & \multicolumn{2}{|c|}{$\begin{array}{l}\text { 3. REPORT TYPE AND DATES COVERED } \\
\text { Technical Memorandum }\end{array}$} \\
\hline \multicolumn{3}{|c|}{$\begin{array}{l}\text { 4. TITLE AND SUBTITLE } \\
\qquad \text { A Heated Tube Facility for Rocket Coolant Channel Research }\end{array}$} & \multirow{2}{*}{$\begin{array}{l}\text { 5. FUNDING NUMBERS } \\
\text { WU-232-01-04 }\end{array}$} \\
\hline \multicolumn{3}{|c|}{$\begin{array}{l}\text { 6. AUTHOR(S) } \\
\text { James M. Green, Gary M. Pease, and Michael L. Meyer }\end{array}$} & \\
\hline $\begin{array}{l}\text { 7. PERFORMING ORGANIZATION } \\
\text { National Aeronautics and } \\
\text { Lewis Research Center } \\
\text { Cleveland, Ohio } 44135 \text { - }\end{array}$ & $\begin{array}{l}\text { AME(S) AND ADDRESS(ES) } \\
\text { pace Administration } \\
191\end{array}$ & & $\begin{array}{l}\text { 8. PERFORMING ORGANIZATION } \\
\text { REPORT NUMBER }\end{array}$ \\
\hline \multicolumn{3}{|c|}{$\begin{array}{l}\text { 9. SPONSORING/MONITORING AGENCY NAME(S) AND ADDRESS(ES) } \\
\text { National Aeronautics and Space Administration } \\
\text { Washington, D.C. } 20546-0001\end{array}$} & $\begin{array}{l}\text { 10. SPONSORING/MONITORING } \\
\text { AGENCY REPORT NUMBER } \\
\text { NASA TM-106968 } \\
\text { AIAA-95-2936 }\end{array}$ \\
\hline \multicolumn{4}{|c|}{$\begin{array}{l}\text { 11. SUPPLEMENTARY NOTES } \\
\text { Prepared for the } 31 \text { st Joint Propulsion Conference and Exhibit, cosponsored by AIAA, ASME, SAE, and ASEE, San } \\
\text { Diego, California, July 10-12, 1995. James M. Green, NYMA, Inc., } 2001 \text { Aerospace Parkway, Brook Park, Ohio } 44142 \\
\text { (work funded by NASA Contract NAS3-27186); Gary M. Pease and Michael L. Meyer, NASA Lewis Research Center. } \\
\text { Responsible person, Gary M. Pease, organization code 5710, (216) 977-7412. }\end{array}$} \\
\hline \multicolumn{3}{|c|}{$\begin{array}{l}\text { 12a. DISTRIBUTIONAVAILABILITY STATEMENT } \\
\text { Unclassified - Unlimited } \\
\text { Subject Categories } 14 \text { and } 20 \\
\text { This publication is available from the NASA Center for Aerospace Information, (301) 621-0390. }\end{array}$} & 12b. DISTRIBUTION CODE \\
\hline \multicolumn{4}{|c|}{$\begin{array}{l}\text { 13. ABSTRACT (Maximum } 200 \text { words) } \\
\text { The canabilities of a heated tube facility used for testing rocket engine coolant chan }\end{array}$} \\
\hline \multirow{2}{*}{\multicolumn{3}{|c|}{$\begin{array}{l}\text { 14. SUBJECT TERMS } \\
\text { Rocket propulsion; Ground testing; Rocket facilities; Heat transfer; RP-1; } \\
\text { Liquid nitrogen; Resistance heating }\end{array}$}} & $\begin{array}{l}\text { 15. NUMBER OF PAGES } \\
11\end{array}$ \\
\hline & & & $\begin{array}{r}\text { 16. PRICE CODE } \\
\text { A03 }\end{array}$ \\
\hline $\begin{array}{l}\text { 17. SECURITY CLASSIFICATION } \\
\text { OF REPORT } \\
\text { Unclassified }\end{array}$ & $\begin{array}{l}\text { 18. SECURITY CLASSIFICATION } \\
\text { OF THIS PAGE } \\
\text { Unclassified }\end{array}$ & $\begin{array}{l}\text { 19. SECURITY CLASSIFICATION } \\
\text { OF ABSTRACT } \\
\text { Unclassified }\end{array}$ & 20. LIMITATION OF ABSTRACT \\
\hline NSN 7540-01-280-5500 & & & $\begin{array}{l}\text { andard Form } 298 \text { (Rev. 2-89) } \\
\text { scribed by ANSI Std. Z39-18 }\end{array}$ \\
\hline
\end{tabular}

